\title{
How to Develop Discourse-based Approach in Second Language
}

\section{Teaching}

\author{
Yun Deng \\ Foreign Language Department, Jiangxi Science\& Technology Normal University, China
} 11577255@qq.com

Keywords: discourse; approach; second language teaching; competence

\begin{abstract}
This article intends to tell us how students can benefit from discourse-based language teaching through two carefully designed tasks. Due to the two listening and writing activities which are based on discourse approaches, students' listening, speaking, reading and writing competence will be strengthened simultaneously. Therefore, discourse-based language teaching integrated with other teaching approaches will be an effective measure to enhance foreign language teaching efficiency.
\end{abstract}

\section{Introduction}

Discourse analysis has been taken up in a variety of disciplines. From the perspective of a discourse theorist [1], "The field of discourse studies has expended into a wide ranging and heterogeneous discipline". The four macro skills-listening, speaking, reading and writing are being widely used and integrated in English teaching. Although each skill emphasizes different approach, they all view language as interaction, and are concerned with the social contexts in which discourse is embedded.

This article aims to show how discourse analysis takes place. These competences are researched by many language theorists. e.g. Canale and Swain, Krashen , Lightbown , Spada, Larsen Freeman , Long and Savignon. In language teaching, one of the objectives is to promote discourse-based approach. The tasks chosen are related to one another. The article also describes how the teacher should present the lesson according to the level of the learners.

\section{The Tasks}

The aim of the chosen tasks is to develop the listening comprehension of the learners and put it into writing. In addition, another goal is to assess the usefulness of a discourse-based teaching approach. "We must also consider the compensatory strategies and communication strategies." [2]

\section{Task 1: Discourse-based Approach to the Listening Teaching}

Each skill has its own role to describe but listening is regarded as the most neglected and difficult of all. Expressing our wants, feelings, thoughts and opinions clearly and effectively is only one part of the communication process. The other part is to listen and understand what others have conveyed to us. An effective communication exists between two people when the receiver interprets and understands the sender's message in the same way the sender intends it. According to Harmer [3], teaching listening depends on the level of the listeners and the kind of tasks that go with the listening 
material. The levels of listeners are beginners, elementary, intermediate, upper intermediate. My students are at intermediate level, hence, the following activities are designed for them. In addition, listening is mainly focused in this task, while as Hinkel [4] notes that in achieving meaningful communication, at least two skills should be applied at the same time. Therefore, speaking is also involved in this task to prop up listening.

\section{Activity I: Pre-listening}

The story is to be introduced entitled "Sand and Stone" by giving students motivation activity. The word FRIENDSHIP will be written on the board. Encouraging students to think of as many words as they know that relate to this key word. Putting down these words outside the circle and using the method of Semantic Webbing.

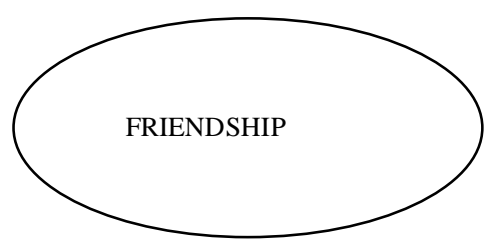

\section{Activity II: Listening}

First Listening: Listen to a short story entitled "Sand and Stone". On the first listening, students are not supposed to write anything. The first listening is often used to give students an idea of what the listening material sounds like so that the subsequent listening is easier for students.

Second Listening: The story will be listened for the second time and students are asked to jot down some important details from the story "Sand and Stone".

\section{Activity III: Post-listening}

This activity mainly consists of:

A. To infer implied meaning of "sand" and "stone" by asking some questions.

B. Comprehensive questions should be provided to determine how well the students understand the story.

1. What is the story about?

2. Who are the main characters in the story?

3. Where did the story happen?

4. Why did the friend slap his friend?

5. What did the other one do?

6. According to the story, what is the difference of writing on the sand and writing on a stone?

C. According to what the students have heard, they are asked to make the sequence of an event by numbering the following statements from 1 to 5 .

The one who slapped and saved his best friend, asked him, "Why, after I hurt you, you wrote in the sand, and now you write on a stone?”

Two friends had an argument and one friend slapped the other one in the face. A story tells that two friends were walking through the desert.

They kept on walking, until they found an oasis, where they decided to take a bath. The one who got slapped and hurt started drowning, and the other friend saved him. 
The other one, smiling, replied: "When a friend hurts us, we should write it down in the sand, where the winds of forgiveness get in charge of erasing it away and when something great happens, we should engrave it in a stone of the memory of the heart, where no wind can erase it".

D. The students are asked to discuss the question "What can you learn form the story?" in groups. Make sure that everyone will share them after the group discussion; two or three representatives will be asked to report what they have learned.

The listening activities are divided into three to show specifications in the given task. Pre-listening is for introducing the lesson by giving them a motivating activity. Semantic webbing is being used to show the main theme of the story. Answers are drawn from students themselves and the teacher should connect those to the lesson material. The motivation is needed to arouse the interest of the learners and to execute the real lesson well. Then the listening material should be presented. What's more, the material presented by teacher should be precise. If the teacher will read the listening text, it should be in a normal tone. While the aim of post-listening is to check whether students have picked up the listening text or not, the art of questioning is vital. Strategies are given to attain the objective of the lesson: firstly, making inferences; secondly, comprehending questions by using the $\mathrm{WH}$ questions; then re-arranging the events according to what they have heard; finally, the reinforcement activity, which is the group discussion.

In listening process, top-down and bottom-up are usually involved. According to Celce Murcia and Olstain [2], "Top-down listening processes involve activation of schematic knowledge and contextual knowledge.” And Carrell [2] also notes that the schemata include background information on the topic. The aim of the first activity is just to help students awake their knowledge and information on this topic. Then the first listening in the next activity is to listen for the gist of the story. It is obviously to be seen that teacher attempts to apply top-down approach to the listening teaching. After that, during the third activity, inferring the implied meaning of the key words "sand" and "stone" reflects bottom-up approach. According to Celce Murcia and Olstain [2], "The bottom-up level of the listening process involves prior knowledge of the language system (i.e., phonology, grammar, vocabulary)”. Teacher intentionally puts bottom-up approach into use in the listening practice. But it is combined with top-down approach rather than being applied automatically. As Celce Murcia [2] claims, "Both top-down and bottom-up listening skills should be integrated and explicitly treated pedagogically to improve L2 listening comprehension. The discourse level is in fact where top-down and bottom-up listening intersect and where complex and simultaneous processing of background information, contextual information, and linguistic information permit comprehension and interpretation to take place." Therefore, top-down and bottom-up listening skills are integrated in this task to achieve the optimal results.

\section{TASK 2: Discourse-based Approach to the Writing Teaching}

"In most writing courses today, students are asked to revise and resubmit assignments after an opportunity to receive some kind of feedback from peers and/ or the instructor. Students are encouraged to understand that the process of writing involves hard work and that improvement is often a result of a major investment of time." [2]. Sometimes, forcing the learners to write is as hard as waking up in a Monday morning. Writing is said to be a daunting task but once ideas pop out it could be overflowing. It is just a matter of how a learner could be motivated to write their thoughts and how words could be a powerful tool to express one's thought.

The two skills may have similarities but as listening is presented on the first day of the class and to be followed by reinforcement on the second day; writing is the best task to integrate. The main 
theme from the listening text can be presented to start up a writing activity. But it should still have motivation on how to jump start a main writing lesson which will be a friendly letter. The procedure will be shown the same with listening task wherein there would be Pre-writing, Writing and Post-writing.

\section{Activity I: Pre-writing}

A quick review will be presented by the teacher and "Sand and Stone" will be written to draw out the topic Friendship in the class. Then ask the motivating question: If you are going to compare your friend to an object, what object would that be? Why?

Possible answer: Pillow because she is very comforting.

\section{Activity II: Writing}

The teacher will present a sample friendly letter and read it so that everyone will follow reading silently.

\section{Country Lane}

North Baysville, CA 53286

July 16, 2007

\section{Dear Susan,}

It feels like such a long time since the last time I saw you. I know it's only been several weeks since I saw you. So far my summer has been great!

I spend my all my weekends at the beach. I am getting a nice tan and you can no longer say I am paler than you. I have been playing lots of volleyball, surfing and building a nice collection of sea shells. Just this past weekend I took second place in a sandcastle building contest!

On the weekdays I work. I drive an ice cream truck around and sell ice cream to the kids. It is so cool. It is a combination of the two things I love most, ice cream and kids. The pay isn't too great but I love the job so much.

I hope the summer's been going well for you too. There's only a month and a half left in summer vacation and after that we will go back to school. Would you like to meet up some time before school starts?

P.S. John Austin says hi.

Your friend,

Signature

After reading the letter, teacher will probe if the learners understand what the letter is all about by asking some questions. Then present the parts of a letter and teach the ways to write a friendly letter.

\section{Activity III: Post-writing}

Present a blank letter and reshuffled paragraphs from the letter. Let the learners re-arrange the letter accordingly.

A. As they are given worksheets, they are to fill in the blanks of the missing words. 
B. Making a friendly letter. Each will be given a clean white paper to write a friendly letter. Make sure to use key points in writing a friendly letter.

In pre-writing activity, the learners should be able to describe their friends by using an inanimate object. Students would be given a minute or two to construct their own sentences to answer. It's also a good activity to arouse their interest in writing the main topic for the lesson. The writing part could be crucial because of the technicalities in making a letter. The sample should be well explained and the parts should be identified properly. The coherency of the task should also be drawn in writing process. The art of questioning is also a must to double check the comprehension of the learners. Furthermore, the sample letter presented in this activity is authentic material. The strength of using the authentic material is noted by Monti [6], “As they learn 'how to learn' by using the materials with functional contexts, they will see that their learning is immediately relevant and transferable. A natural extension of this is that rapport is built, a social network can be created, and ideally, retention rates will increase." In addition, the post-writing is the reinforcement of the lesson that should be acquired by the learners.

\section{Conclusion}

From the tasks some discourse-based approaches have been applied to stimulate students into developing their language ability, and engage them with practical activities from the beginning. During the process of engaging in all of these activities, students will promote their listening, speaking and writing skills and be thoroughly versed in dealing with them in depth. Based on it, students can have a slightly "mature” language competence, so that they can learn a lot through a discourse-based approach effectively [1, 2]. In brief, discourse-based approach is available and helpful for both teachers and students.

\section{Appendix}

\section{Sand and Stone}

A story tells that two friends were walking through the desert. In a specific point of the journey, they had an argument, and one friend slapped the other one in the face. The one, who got slapped, was hurt, but without anything to say, he wrote in the sand: "TODAY, MY BEST FRIEND SLAPPED ME IN THE FACE.”

They kept on walking, until they found an oasis, where they decided to take a bath. The one who got slapped and hurt started drowning, and the other friend saved him. When he recovered from the fright, he wrote on a stone: "TODAY MY BEST FRIEND SAVED MY LIFE.”

The friend who saved and slapped his best friend, asked him, "Why, after I hurt you, you wrote in the sand, and now you write on a stone?"

The other one, smiling, replied: "When a friend hurts us, we should write it down in the sand, where the winds of forgiveness get in charge of erasing it away and when something great happens, we should engrave it in a stone of the memory of the heart, where no wind can erase it”.

\section{References}

[1] Barraja-Rohan, A. Teaching Conversation and Sociocultural Norms with Conversational Analysis. Australian Review of Applied Linguistics[J], 1997 14 71-88. 
[2] Celce-Murcia, M., and Olshtain, E. Discourse and Context in Language Teaching: A Guide for Language Teachers[M]. Cambridge: Cambridge University Press. 2000.105.

[3] Harmer, J. The Practice of English Language Teaching[M]. London: Longman ELT. 2007.221.

[4] Hinkel, E. Current Perspective in Teaching the Four Skills[J]. TESOL Quarterly 2006 40(1) 109-131.

[5] Monti, M. Integration of learn roles and authentic materials in the adult education context. Retrieved on $28^{\text {th }}$ May, 2009 from http://www.pde.state.pa.us/able/lib/able/fieldnotes06/ fn06authentic.pdf(2006) 